\title{
Front Matter: Volume 8538
}

, "Front Matter: Volume 8538," Proc. SPIE 8538, Earth Resources and Environmental Remote Sensing/GIS Applications III, 853801 (9 November 2012); doi: $10.1117 / 12.2014369$

SPIE. Event: SPIE Remote Sensing, 2012, Edinburgh, United Kingdom 


\title{
Earth Resources and
}

\section{Environmental Remote}

Sensing/GIS Applications III

\author{
Daniel L. Civco \\ Manfred Ehlers \\ Shahid Habib \\ Antonino Maltese \\ David Messinger \\ Ulrich Michel \\ Konstantinos G. Nikolakopoulos \\ Karsten Schulz \\ Editors
}

\section{4-26 September 2012 \\ Edinburgh, United Kingdom}

Sponsored by

SPIE

Cosponsored by

SELEX GALILEO

THALES

Delivered with the support of

Scottish Development International

Scottish Enterprise

\section{Cooperating Organisations}

European Association of Remote Sensing Companies (Belgium) • Remote Sensing and

Photogrammetry Society (United Kingdom) • Scottish Optoelectronics Association (United

Kingdom) •Electronics Sensors and Photonics Knowledge Transfer Network (United Kingdom)

Published by

SPIE

Volume 8538 
The papers included in this volume were part of the technical conference cited on the cover and title page. Papers were selected and subject to review by the editors and conference program committee. Some conference presentations may not be available for publication. The papers published in these proceedings reflect the work and thoughts of the authors and are published herein as submitted. The publisher is not responsible for the validity of the information or for any outcomes resulting from reliance thereon.

Please use the following format to cite material from this book:

Author(s), "Title of Paper," in Earth Resources and Environmental Remote Sensing/GIS Applications III, edited by Daniel L. Civco, Manfred Ehlers, Shahid Habib, Antonino Maltese, David Messinger, Ulrich Michel, Konstantinos G. Nikolakopoulos, Karsten Schulz, Proceedings of SPIE Vol. 8538 (SPIE, Bellingham, WA, 2012) Article CID Number.

ISSN: 0277-786X

ISBN: 9780819492784

Published by

SPIE

P.O. Box 10, Bellingham, Washington 98227-0010 USA

Telephone +1 3606763290 (Pacific Time) · Fax +1 3606471445

SPIE.org

Copyright (c) 2012, Society of Photo-Optical Instrumentation Engineers.

Copying of material in this book for internal or personal use, or for the internal or personal use of specific clients, beyond the fair use provisions granted by the U.S. Copyright Law is authorized by SPIE subject to payment of copying fees. The Transactional Reporting Service base fee for this volume is $\$ 18.00$ per article (or portion thereof), which should be paid directly to the Copyright Clearance Center (CCC), 222 Rosewood Drive, Danvers, MA 01923. Payment may also be made electronically through CCC Online at copyright.com. Other copying for republication, resale, advertising or promotion, or any form of systematic or multiple reproduction of any material in this book is prohibited except with permission in writing from the publisher. The CCC fee code is 0277-786X/12/\$18.00.

Printed in the United States of America.

Publication of record for individual papers is online in the SPIE Digital Library.

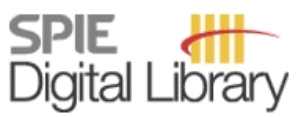

SPIEDigitallibrary.org

Paper Numbering: Proceedings of SPIE follow an e-First publication model, with papers published first online and then in print and on CD-ROM. Papers are published as they are submitted and meet publication criteria. A unique, consistent, permanent citation identifier (CID) number is assigned to each article at the time of the first publication. Utilization of CIDs allows articles to be fully citable as soon as they are published online, and connects the same identifier to all online, print, and electronic versions of the publication. SPIE uses a six-digit CID article numbering system in which:

- The first four digits correspond to the SPIE volume number.

- The last two digits indicate publication order within the volume using a Base 36 numbering

system employing both numerals and letters. These two-number sets start with 00, 01, 02, 03, 04, $05,06,07,08,09,0 A, 0 B \ldots$. 0Z, followed by 10-1Z, 20-2Z, etc.

The CID Number appears on each page of the manuscript. The complete citation is used on the first page, and an abbreviated version on subsequent pages. Numbers in the index correspond to the last two digits of the six-digit CID Number. 


\title{
Contents
}

\author{
ix Conference Committee \\ xiii Introduction
}

\section{Part A Earth Resources and Environmental Remote Sensing/GIS Applications}

\author{
REMOTE SENSING PLENARY SESSION
}

853802 Maximizing the use of EO products: how to leverage the potential of open geospatial service architectures (Plenary Paper) [8538-100]

T. Usländer, Fraunhofer-Institut für Optronik, Systemtechnik und Bildauswertung (Germany)

PROCESSING METHODOLOGIES I: ACCURACY ASSESSMENT

853803 Monitoring of changes in areas of conflicts: the example of Darfur [8538-1]

H. Thunig, U. Michel, Univ. of Education Heidelberg (Germany)

853804 Detection and assessment of land use dynamics on Tenerife (Canary Islands): the agricultural development between 1986 and 2010 [8538-2]

S. Günthert, Univ. of Education Heidelberg (Germany) and Ruprecht-Karls-Univ. Heidelberg (Germany); S. Naumann, Univ. of Education Heidelberg (Germany); A. Siegmund, Univ. of Education Heidelberg (Germany) and Ruprecht-Karls-Univ. Heidelberg (Germany)

853805 Assessing the spatial fidelity of resolution-enhanced imagery using Fourier analysis: a proof-of-concept study [8538-3]

D. L. Civco, C. Witharana, Univ. of Connecticut (United States)

\section{HAZARD MITIGATION GEOLOGIC APPLICATION I}

853806 Change detection in time series of high resolution SAR satellite images [8538-4] M. Boldt, K. Schulz, Fraunhofer-Institut für Optronik, Systemtechnik und Bildauswertung (Germany)

853807 Evaluating remote sensing image fusion algorithms for use in humanitarian crisis management [8538-5]

C. Witharana, D. L. Civco, Univ. of Connecticut (United States)

853808 Comparison of 3D representations depicting micro folds: overlapping imagery vs. time-offlight laser scanner [8538-6]

A. D. Vaiopoulos, A. Georgopoulos, National Technical Univ. of Athens (Greece);

S. G. Lozios, National and Kapodistrian Univ. of Athens (Greece) 
853809 Analysis of time series geospatial data for seismic precursors detection in Vrancea zone [8538-7]

M. A. Zoran, R. S. Savastru, D. M. Savastru, National Institute of Research and Development

for Optoelectronics (Romania)

PROCESSING METHODOLOGIES II

8538 OA Data service platform for MODIS Vegetation Indices time series processing at BOKU Vienna: current status and future perspectives [8538-9]

F. Vuolo, M. Mattiuzzi, A. Klisch, C. Atzberger, Univ. of Natural Resources and Life Sciences, BOKU (Austria)

8538 OB Development of a low altitude airborne remote sensing system for supporting the processing of satellite remotely sensed data intended for archaeological investigations [8538-10]

A. Agapiou, D. G. Hadjimitsis, Cyprus Univ. of Technology (Cyprus); A. Georgopoulos, National Technical Univ. of Athens (Greece); K. Themistocleous, D. D. Alexakis, Cyprus Univ. of Technology (Cyprus); G. Papadavid, Agricultural Research Institute (Cyprus)

8538 OD A new time-to-digital converter for the 3D imaging Lidar [8538-12]

C. Hu, Z. Huang, S. Qin, F. Hu, National Univ. of Defense Technology (China)

INFRASTRUCTURES AND URBAN AREAS

$8538 \mathrm{OE}$ Object-based urban change detection analyzing high resolution optical satellite images [8538-13]

M. Boldt, Fraunhofer-Institut für Optronik, Systemtechnik und Bildauswertung (Germany); A. Thiele, Fraunhofer-Institut für Optronik, Systemtechnik und Bildauswertung (Germany) and Karlsruher Institut für Technologie (Germany); K. Schulz, Fraunhofer-Institut für Optronik, Systemtechnik und Bildauswertung (Germany)

$8538 \mathrm{OF}$ Integrated data processing of remotely sensed and vector data for building change detection [8538-14]

N. Sofina, M. Ehlers, Univ. Osnabrück (Germany); U. Michel, Univ. of Education Heidelberg (Germany)

8538 OG Ad-hoc model acquisition for combat simulation in urban terrain [8538-15]

D. Bulatov, P. Solbrig, P. Wernerus, Fraunhofer-Institut für Optronik, Systemtechnik und Bildauswertung (Germany)

$8538 \mathrm{OH}$ Integrating machine learning techniques and high-resolution imagery to generate GISready information for urban water consumption studies [8538-16]

N. Wolf, A. Hof, Ruhr-Univ. Bochum (Germany)

8538 Ol 3D campus modeling using LiDAR point cloud data [8538-17]

Y. Kawata, S. Yoshii, Y. Funatsu, K. Takemata, Kanazawa Institute of Technology (Japan) 
8538 0J Multitemporal satellite data in mine waste monitoring of Medet copper deposit [8538-18]

D. Borisova, H. Nikolov, D. Petkov, Space Research and Technology Institute (Bulgaria);

B. Banushev, Univ. of Mining and Geology (Bulgaria)

8538 OK Statistical frameworking of deforestation models based on human population density and relief energy [8538-19]

R. Nishii, D. Miyata, Kyushu Univ. (Japan); S. Tanaka, Shimane Univ. (Japan)

$8538 \mathrm{OL}$ Object-oriented industrial solid waste identification using $\mathrm{HJ}$ satellite imagery: a case study of phosphogypsum [8538-20]

Z. Fu, W. Shen, R. Xiao, W. Xiong, Y. Shi, Ministry of Environmental Protection (China);

B. Chen, Chinese Academy of Fishery Sciences (China)

\section{ENVIRONMENTAL MONITORING I}

8538 OP A comparison of selected machine learning classifiers in mapping a South African heterogeneous coastal zone: Testing the utility of an object-based classification with WorldView-2 imagery [8538-24]

E. M. I. Adam, R. Ismail, O. Mutanga, Univ. of KwaZulu-Natal (South Africa)

\section{ENVIRONMENTAL MONITORING II}

8538 OR Per-field crop classification in irrigated agricultural regions in middle Asia using random forest and support vector machine ensemble [8538-26]

F. Löw, G. Schorcht, Julius-Maximilians-Univ. Würzburg (Germany); U. Michel, Univ. of Education Heidelberg (Germany); S. Dech, Julius-Maximilians-Univ Würzburg (Germany) and Deutsches Zentrum für Luft- und Raumfahrt e.V. (Germany); C. Conrad, JuliusMaximilians-Univ. Würzburg (Germany)

8538 OS Spatio-temporal robustness of fractional cover upscaling: a case study in semi-arid Savannah's of Namibia and Western Zambia [8538-27]

J. Zeidler, M. Wegmann, Julius-Maximilians-Univ. Würzburg (Germany); S. Dech, Julius-

Maximilians-Univ. Würzburg (Germany) and Deutsches Zentrum für Luft- und Raumfahrt e.V. (Germany)

8538 OV SPOT5 imagery for soil salinity assessment in Iraq [8538-31]

S. Teggi, S. Costanzini, F. Despini, P. Chiodi, Univ. degli Studi di Modena e Reggio Emilia (Italy); F. Immordino, ENEA (Italy)

ENVIRONMENTAL MONITORING III

8538 OW Object-based cropland degradation identification: a case study in Uzbekistan [8538-32] O. Dubovyk, G. Menz, Univ. of Bonn (Germany); C. Conrad, Univ. of Würzburg (Germany); A. Khamzina, Univ. of Bonn (Germany) 
8538 0X Spatiotemporal object-based image analyses in the Blue Nile area using optical multispectral imagery [8538-33]

M. M. El-Abbas, Technische Univ. Dresden (Germany) and Univ. of Khartoum (Sudan);

E. Csaplovics, Technische Univ. Dresden (Germany)

8538 OY Total ozone column distribution over peninsular Malaysia from scanning imaging absorption spectrometer for atmospheric cartography (SCIAMACHY) [8538-35]

K. C. Tan, H. S. Lim, M. Z. MatJafri, Univ. Sains Malaysia (Malaysia)

$85380 Z$ Combine MODIS and HJ-1 CCD NDVI with logistic model to generate high spatial and temporal resolution NDVI data [8538-36]

J. Jiang, J. Song, J. Wang, Z. Xiao, Beijing Normal Univ. (China)

853810 Remote sensing indices for monitoring land degradation in a semiarid to arid basin in Jordan [8538-37]

J. Al-Bakri, H. Saoub, The Univ. of Jordan (Jordan); W. Nickling, Univ. of Guelph (Canada);

A. Suleiman, The Univ. of Jordan (Jordan); M. Salahat, The Hashemite Univ. (Jordan);

S. Khresat, Jordan Univ. of Science \& Technology (Jordan); T. Kandakji, The Univ. of Jordan

(Jordan)

\section{Part B Special Joint Session on Remote Sensing and Natural Disasters: Remote Sensing 2012}

NATURAL DISASTERS I

$853811 \quad$ An automated approach to flood mapping [8538-70]

W. Sun, D. M. Mckeown, D. W. Messinger, Rochester Institute of Technology (United States)

853813 Flood delineation from synthetic aperture radar data with the help of a priori knowledge from historical acquisitions and digital elevation models in support of near-real-time flood mapping [8538-73]

S. Schlaffer, M. Hollaus, W. Wagner, Technische Univ. Wien (Austria); P. Matgen, Ctr. de Recherche Public - Gabriel Lippmann (Luxembourg)

853814 Anomalously strong bora events in the NE part of the Black Sea imaged and studied with SAR and optical imagery [8538-74]

A. Y. Antonyuk, ScanEx Research and Development Ctr. (Russian Federation); A. Y. Ivanov, P.P. Shirshov Institute of Oceanology (Russian Federation)

853815 A new automatic synthetic aperture radar-based flood mapping application hosted on the European Space Agency's Grid Processing of Demand Fast Access to Imagery environment [8538-76]

P. Matgen, L. Giustarini, R. Hostache, Ctr. de Recherche Public - Gabriel Lippmann

(Luxembourg) 
853816 Monitoring El Hierro submarine volcano with low and high resolution satellite images [8538-79]

F. Eugenio, J. Marcello, J. Martin, Univ. de Las Palmas de Gran Canaria (Spain)

853817 Research study on appropriate interpretation techniques of satellite images for natural disaster management [8538-80]

M. Poursaber, Kobe Univ. (Japan) and Abbaspour Univ. of Technology (Iran, Islamic Republic of); Y. Ariki, Kobe Univ. (Japan); M. Safi, Abbaspour Univ. of Technology (Iran, Islamic Republic of)

853818 Detecting spatio-temporal changes in the extent of seasonal and annual flooding in South Asia using multi-resolution satellite data [8538-81]

G. Amarnath, M. Ameer, International Water Management Institute (Sri Lanka);

P. Aggarwal, International Water Management Institute (India); V. Smakhtin, International Water Management Institute (Sri Lanka)

853819 The effects of orography on cloud and rainfall patterns during typhoon Ketsana (2009) [8538-82]

T. Fuyi, M. Z. MatJafri, H.-S. Lim, K. Abdullah, Univ. Sains Malaysia (Malaysia)

POSTER SESSION

8538 1C The application of remote sensing in the environmental risk monitoring of tailings pond: a case study in Zhangjiakou area of China [8538-38]

R. Xiao, W. Shen, Z. Fu, Y. Shi, W. Xiong, F. Cao, Ministry of Environmental Protection (China)

$8538 \mathrm{IF} \quad$ Satellite remote sensing data for urban heat waves assessment and human health impacts [8538-41]

M. A. Zoran, National Institute of Research and Development for Optoelectronics

(Romania); M. R. Dida, Univ. of Medicine and Pharmacy of Craiova (Romania)

$85381 \mathrm{H} \quad$ A new time discrimination circuit for the 3D imaging lidar [8538-43]

C. Hu, Z. Huang, S. Qin, X. Wang, National Univ. of Defense Technology (China)

8538 1I Long term seismic noise acquisition and analysis with tunable monolithic horizontal sensors at the INFN Gran Sasso National Laboratory [8538-44]

F. Acernese, R. Canonico, Univ. degli Studi di Salerno (Italy) and Istituto Nazionale di Fisica Nucleare (Italy); R. De Rosa, Istituto Nazionale di Fisica Nucleare (INFN) (Italy) and Univ. degli Studi di Napoli Federico II (Italy); G. Giordano, Univ. degli Studi di Salerno (Italy); R. Romano, F. Barone, Univ. degli Studi di Salerno (Italy) and Istituto Nazionale di Fisica Nucleare (Italy)

$85381 \mathrm{~J} \quad$ Low frequency/high sensitivity horizontal monolithic sensor [8538-45]

F. Acernese, Univ. degli Studi di Salerno (Italy) and Istituto Nazionale di Fisica Nucleare (Italy); R. Canonico, Univ. degli Studi di Salerno (Italy); R. De Rosa, Istituto Nazionale di Fisica Nucleare (Italy) and Univ. degli Studi di Napoli Federico II (Italy); G. Giordano, Univ. degli Studi di Salerno (Italy); R. Romano, F. Barone, Univ. degli Studi di Salerno (Italy) and Istituto Nazionale di Fisica Nucleare (Italy) 
$85381 \mathrm{~K}$ Performance of commercial and open source remote sensing/image processing software for land cover/use purposes [8538-46]

A. C. Teodoro, D. Ferreira, N. Sillero, Univ. do Porto (Portugal)

$85381 \mathrm{~L} \quad$ Mechanical monolithic tiltmeter for low frequency measurements [8538-47]

F. Acernese, R. Canonico, Univ. degli Studi di Salerno (Italy) and Istituto Nazionale di Fisica Nucleare (Italy); R. De Rosa, Istituto Nazionale di Fisica Nucleare (Italy) and Univ. degli Studi di Napoli Federico II (Italy); G. Giordano, Univ. degli Studi di Salerno (Italy); R. Romano, F. Barone, Univ. degli Studi di Salerno (Italy) and Istituto Nazionale di Fisica Nucleare (Italy)

8538 IM Monitoring the burst-out of Enteromorpha prolifera in the Yellow Sea of China [8538-48] H. Li, H. Peng, H. Zhang, Huaihai Institute of Technology (China); C. Huang, Cold and Arid Regions Environmental and Engineering Research Institute (China)

$85381 \mathrm{~N}$ The feasibility of landscape pattern analysis within the alpine steppe of the Yellow River source based on historical CORONA panchromatic imagery [8538-49]

Q. Jiao, B. Zhang, L. Liu, Ctr. for Earth Observation and Digital Earth (China)

8538 1P Evaluation of wind flow computational models using multi-resolution remote sensing datasets in a high complexity terrain domain [8538-51]

J. Koutroumpas, K. Koutroumpas, InfoMETRICS Consulting Engineers Ltd. (Greece)

$85381 Q \quad$ Coastal morphodynamic features/patterns analisys through a video-based system and image processing [8538-52]

F. Santos, J. Pais-Barbosa, A. C. Teodoro, H. Gonçalves, Univ. do Porto (Portugal);

P. Baptista, Univ. de Aveiro (Portugal); A. Moreira, F. Veloso-Gomes, F. Taveira-Pinto,

P. Gomes-Costa, V. Lopes, F. Neves-Santos, Univ. do Porto (Portugal)

8538 is Landslide detection using ALOS optical data: the case of Sykies Village in Andritsena, Greece [8538-54]

K. G. Nikolakopoulos, Univ. of Patras (Greece)

$85381 T \quad$ GIS4schools: a new approach in GIS education [8538-55]

T. Demharter, U. Michel, Univ. of Education Heidelberg (Germany)

$85381 \mathrm{~V} \quad$ Monitoring land cover dynamics in the Aral Sea region by remote sensing [8538-58]

G. Kozhoridze, L. Orlovsky, N. Orlovsky, Ben-Gurion Univ. of the Negev (Israel)

8538 IW A research framework of payments for environmental services of island based on remote sensing [8538-61]

L. Wang, The Second Institute of Oceanography (China) and Guangdong Ocean Univ. (China); J. Cheng, Q. Liu, D. Fu, The Second Institute of Oceanography (China)

Author Index 


\section{Conference Committee}

Symposium Chair

Karin Stein, Fraunhofer-Institut für Optronik, Systemtechnik und

Bildauswertung (Germany)

Symposium Cochair

Charles R. Bostater Jr., Florida Institute of Technology (United States)

\section{Part A Earth Resources and Environmental Remote Sensing/GIS Applications}

Conference Chairs

Ulrich Michel, University of Education Heidelberg (Germany)

Daniel L. Civco, University of Connecticut (United States)

Conference CoChairs

Manfred Ehlers, Universität Osnabrück (Germany)

Karsten Schulz, Fraunhofer-Institut für Optronik, Systemtechnik und Bildauswertung (Germany)

Konstantinos G. Nikolakopoulos, University of Patras (Greece)

Conference Programme Committee

Thomas Blaschke, Universität Salzburg (Austria)

Tilman U. Bucher, Deutsches Zentrum für Luft- und Raumfahrt e.V. (Germany)

Ni-Bin Chang, University of Central Florida (United States)

Garik Gutman, NASA Headquarters (United States)

Martin Kappas, Georg-August- Universität Göttingen (Germany)

Rosa Lasaponara, Consiglio Nazionale delle Ricerche (Italy)

Marguerite M. Madden, The University of Georgia (United States)

Derya Maktav, Istanbul Technical University (Turkey)

Nicola Masini, Consiglio Nazionale delle Ricerche (Italy)

Matthias S. Moeller, Beuth University of Applied Sciences Berlin

(Germany)

Pablo H. Rosso, Universität Osnabrück (Germany)

Florian Savopol, Natural Resources Canada (Canada)

Jochen Schiewe, HafenCity Universität Hamburg (Germany) 
Wenzhong Shi, The Hong Kong Polytechnic University (Hong Kong, China)

Alexander Siegmund, University of Education Heidelberg (Germany)

Karl Staenz, University of Lethbridge (Canada)

Josef Strobl, Universität Salzburg (Austria)

John L. van Genderen, International Institute for Geo-Information Science and Earth Observation (Netherlands)

Kerstin Voss, Rheinische Friedrich-Wilhelms- Universität Bonn (Germany)

Christiane H. Weber, University of Strasbourg/Faculty of Geography (France)

\section{Session Chairs}

1 Processing Methodologies I: Accuracy Assessment

Ulrich Michel, University of Education Heidelberg (Germany)

Daniel L. Civco, University of Connecticut (United States)

2 Hazard Mitigation Geologic Application I

Konstantinos G. Nikolakopoulos, University of Patras (Greece)

3 Processing Methodologies II

Pablo H. Rosso, Universität Osnabrück (Germany)

4 Infrastructures and Urban Areas

Karsten Schulz, Fraunhofer-Institut für Optronik, Systemtechnik und Bildauswertung (Germany)

5 Hazard Mitigation Geologic Application II

Konstantinos G. Nikolakopoulos, University of Patras (Greece)

6 Environmental Monitoring I

Markus Boldt, Fraunhofer-Institut für Optronik, Systemtechnik und Bildauswertung (Germany)

7 Environmental Monitoring II

Karsten Schulz, Fraunhofer-Institut für Optronik, Systemtechnik und Bildauswertung (Germany)

8 Environmental Monitoring III

Sebastian Günthert, University of Education Heidelberg (Germany) 


\section{Part B Special Joint Session on Remote Sensing and Natural Disasters: Remote Sensing 2012}

\section{Conference Chairs}

Shahid Habib, NASA Goddard Space Flight Center (United States)

David Messinger, Rochester Institute of Technology (United States)

Antonino Maltese, Università degli Studi di Palermo (Italy)

\section{Conference Programme Committee}

Harold Annegarn, University of Johannesburg (South Africa)

Charles R. Bostater Jr., Florida Institute of Technology (United States)

Safwat Dayem, Arab Water Council (Egypt)

Ayman El-Dessouki, National Authority for Remote Sensing and Space Sciences (Egypt)

Ahmed Erraji, Centre Royal de Teledetection Spatiale du Maroc (Morocco)

Diego Fernández-Prieto, ESRIN (Italy)

Mario Hernandez, United Nations Educational, Scientific and Cultural Organization (France)

Steve Iris, Canadian Space Agency (Canada)

Umar Khatick, National University of Sciences and Technology (Pakistan)

Claire Kfouri, The World Bank (United States)

Rachael McDonnell, University of Oxford (United Kingdom)

Dimitar P. Ouzounov, NASA Goddard Space Flight Center (United States)

Mutlu Ozdogan, University of Wisconsin-Milwaukee (United States)

Imran Saloojee, Group on Earth Observations (Switzerland)

Ramesh P. Singh, Chapman University (United States)

Si-Chee Tsay, NASA Goddard Space Flight Center (United States)

Tsehaie Woldai, International Institute for Geo-Information Science \& Earth Observation (Netherlands)

\section{Session Chairs}

10 Natural Disasters I

Shahid Habib, NASA Goddard Space Flight Center (United States)

11 Natural Disasters II

David Messinger, Rochester Institute of Technology (United States) 
Proc. of SPIE Vol. 8538 853801-12

Downloaded From: https://www.spiedigitallibrary.org/conference-proceedings-of-spie on 25 Apr 2023 Terms of Use: https://www.spiedigitallibrary.org/terms-of-use 


\section{Introduction to Part A: Earth Resources and Environmental Remote Sensing/GIS Applications}

These proceedings contain 53 papers that were presented at the SPIE Conference "Earth Resources and Environmental Remote Sensing/GIS Applications" (Conference 8538A) formerly known under the title "Remote Sensing for Environmental Monitoring, GIS Applications, and Geology'. The Conference took place in Edinburgh, United Kingdom from 24 September to 27 September 2012. It was the twelfth Conference with this topic after its inauguration in Toulouse, France, in 2001.

The Conference sessions with presented papers and interactive posters were grouped into the following themes: Processing Methodologies, Hazard Mitigation Geologic Application, Processing Methodologies, Infrastructures and Urban Areas and Environmental Monitoring.

Lively discussions often continued into the coffee breaks. Although the session topics seemed rather diverse, there was a common thread to many papers, i.e., application of remotely sensed data for the protection of our environment and Change Detection. There was strong support from the audience to continue these themes for future conferences.

The paper submission and review process were again perfectly organized by the SPIE staff. We like to thank the SPIE staff on-site for their responsiveness and support. We are also grateful to our Program Committee for their help in the reviewing and session compilation process.

Ulrich Michel Daniel L. Civco 
Proc. of SPIE Vol. 8538 853801-14

Downloaded From: https://www.spiedigitallibrary.org/conference-proceedings-of-spie on 25 Apr 2023 Terms of Use: https://www.spiedigitallibrary.org/terms-of-use 